Article

\title{
Sustainable Durio zibethinus-Derived Biosorbents for Congo Red Removal from Aqueous Solution: Statistical Optimization, Isotherms and Mechanism Studies
}

\author{
A. A. Oyekanmi ${ }^{1}$, Akil Ahmad ${ }^{2,3, * \mathbb{C}}$, Siti Hamidah Mohd Setapar ${ }^{3}$, Mohammed B. Alshammari ${ }^{2}$ (I), \\ Mohammad Jawaid ${ }^{4}\left(\mathbb{D}\right.$, Marlia Mohd Hanafiah ${ }^{5,6}$, H. P. S. Abdul Khalil ${ }^{1}{ }^{(\mathbb{C}}$ and Ashok Vaseashta ${ }^{7,8, *}$
}

1 School of Industrial Technology, Universiti Sains Malaysia, Gelugor 11800, Malaysia; abdulkan2000@yahoo.com (A.A.O.); akhalilhps@gmail.com (H.P.S.A.K.)

2 Chemistry Department, College of Sciences and Humanities, Prince Sattam Bin Abdulaziz University, P.O. Box 83, Al-Kharj 11942, Saudi Arabia; m.alshammari@psau.edu.sa

3 Centre of Lipids Engineering and Applied Research, Universiti Teknologi Malaysia, Johor Bahru 81310, Malaysia; siti-h@utm.my

4 Laboratory of Biocomposite Technology, Institute of Tropical Forestry and Forest Products (INTROP), Universiti Putra Malaysia, Seri Kembangan 43400, Malaysia; jawaid@upm.edu.my

5 Department of Earth Sciences and Environment, Faculty of Science and Technology, The National University of Malaysia (UKM), Bangi 43600, Malaysia; mhmarlia@ukm.edu.my

6 Centre for Tropical Climate Change System, Institute of Climate Change, The National University of Malaysia (UKM), Bangi 43600, Malaysia

check for

updates

Citation: Oyekanmi, A.A.; Ahmad, A.; Mohd Setapar, S.H.; Alshammari, M.B.; Jawaid, M.; Hanafiah, M.M.; Abdul Khalil, H.P.S.; Vaseashta, A. Sustainable Durio zibethinus-Derived Biosorbents for Congo Red Removal from Aqueous Solution: Statistical Optimization, Isotherms and Mechanism Studies. Sustainability 2021, 13, 13264. https://doi.org/ $10.3390 /$ su132313264

Academic Editor: Luca Di Palma

Received: 20 August 2021

Accepted: 4 October 2021

Published: 30 November 2021

Publisher's Note: MDPI stays neutral with regard to jurisdictional claims in published maps and institutional affiliations.

Copyright: (c) 2021 by the authors. Licensee MDPI, Basel, Switzerland. This article is an open access article distributed under the terms and conditions of the Creative Commons Attribution (CC BY) license (https:/ / creativecommons.org/licenses/by/ $4.0 /)$.
7 Office of Applied Research, International Clean Water Institute, Manassas, VA 20112, USA

8 Biomedical Engineering and Nanotechnologies Institute, Riga Technical University, 1658 Riga, Latvia

* Correspondence: aj.ahmad@psau.edu.sa (A.A.); prof.vaseashta@ieee.org (A.V.)

\begin{abstract}
This investigation reports on the biosorption mechanism of Congo Red dyes (CR) in aqueous solution using acid-treated durian peels, prepared for this study. The biosorbent nature was characterized using the Scanning Electron Microscopy (SEM), Fourier Transform infrared spectroscopy (FT-IR) and Brunaure-Emmet-Teller (BET). The effect of process parameters within operational range of $\mathrm{pH}(2-9)$, contact time (10-200 min), initial concentration (25-400 $\mathrm{mg} \mathrm{g}^{-1}$ ) and temperature $\left(25-65^{\circ} \mathrm{C}\right)$ for the optimum removal of $\mathrm{CR}$ dyes was investigated using central composite design (CCD) under response surface methodology (RSM), and revealed that the optimum condition of biosorption was achieved around a $\mathrm{pH}$ of 5.5, contact time of $105 \mathrm{~min}$ at initial concentration of $212.5 \mathrm{mg} \mathrm{L}^{-1}$ within $45^{\circ} \mathrm{C}$ temperature, which corresponds to $95.2 \%$ percent removal of $\mathrm{CR}$. The experimental data fitted better to the second order polynomial model, with a correlation coefficient $\mathrm{R}^{2}$ value of 0.9917 and the Langmuir isotherm model with biosorption capacity of $107.52 \mathrm{mg} \mathrm{g}^{-1}$. Gibbs free energy indicated that the adsorption of CR dyes was spontaneous. The mechanism of the adsorption of $\mathrm{CR}$ dyes revealed that the biosorption of CR dyes investigated under different operational conditions show that under acidic $\mathrm{pH}$, the adsorption efficiency of the acid treated durian peels is enhanced for the adsorption of CR dye molecules.
\end{abstract}

Keywords: Congo Red; biosorption; durian peels; central composite design; environmental sustainability mechanism

\section{Introduction}

In the last few decades, a large amount of colour effluents have been generated from various industries such as textiles, leather and pharmaceuticals. According to some recent estimates, over half a million tons of Congo red (CR) anionic diazo dyes are produced annually [1]. CR dyes are widely applied in many manufacturing industries such as plastic, paper, leather, silk, cotton and hemp [2]. The residual dyes are the major contributor to the colour in the effluents generated by these industries. These residual dyes contain complex chemical structures, several aromatic rings, and functional groups that are very difficult 
to biodegrade [3,4]. They can be persistent for a long time in the environment, thereby causing pollution. Furthermore, most of these colours are mutagenic and carcinogenic in nature and can cause many diseases, resulting in adverse effects on the aquatic ecosystem and living beings, including humans [4]. In the same context, these dyes are contained in most of the industrial wastewater all over the world and can easily be released into the surface and ground water [3]. Therefore, studies on the removal of recalcitrant dyes such as CR synthetic dyes is urgent and environmentally significant [5]. Due to the complex chemical structure, it is very difficult to remove them from wastewater and water reservoirs by using commonly used decontamination techniques, including chemical precipitation [6], reverse osmosis [7], solvent extraction [8], photocatalytic processes [9], ion exchange [10], ultrafiltration [11], coagulation, flocculation [12] and adsorption [13-15]. In the past few decades, adsorption has been the preferential treatment for reactive dye adsorption due to its simple operation, effective treatment and widespread applicability [16] Many studies have reported on CR dye biosorption from aqueous solution [17-27]. However, none have investigated CR dyes using durian peels. Malaysia and Indonesia are the world's two major durian (Durio zibethinus) producing countries. Durian is considered the "King of Fruits" in the Southeast Asia peninsula. It is a seasonal dicotyledonous plant with large size fruits (weight: 1 to $3 \mathrm{~kg}$, length: 2 to $7 \mathrm{lb}$. and dark green in colour) and dreadful thorn-covered husk. Overall durian production in Malaysia is more than 300,470 million tons and 255,353 million tons of durian shells ends as by-products per year, according to reported data by the Agricultural and Agro-based Industry Malaysia [28]. During durian season, agro-waste is the predominant waste all over the Malaysian peninsula, and this could potentially become a future environmental challenge [29].

Motivated by the environmental impacts of durian wastes, which, in turn, can be used as a potential biosorbent for the removal of dye containing effluents, the main objective of this research was to prepare and characterize chemically treated durian peels as an alternative biosorbents for the removal of CR dye from aqueous solution. This study is aimed to optimize the effect of the processing parameters of CR dye removal on the biosorbent in a batch experiment using statistical model. Experimental biosorption data were fitted to Langmuir, Freundlich and Temkin isotherm models. Kinetic studies were investigated using Pseudo first order, Pseudo second order and the intraparticle diffusion equations. Vant hoff's thermodynamic parameter was used to study the effect of temperature on the sorption capacity of the biosorbent. Moreover, the mechanism of the biosorbent efficiency for CR dye removal was also included in the study.

\section{Materials and Methods}

\subsection{Adsorbate Preparation}

The Congo red dye, namely (3,3'-(Biphenyl-4, $4^{\prime}$-diyldidiazene-2,1-diyl)bis (4-aminonaphthalene-1-sulfonic acid)); molecular formula: $\mathrm{C}_{32} \mathrm{H}_{22} \mathrm{~N}_{6} \mathrm{Na}_{2} \mathrm{O}_{6} \mathrm{~S}_{2}$; molar mass: $696.7 \mathrm{~g} / \mathrm{mol}$, was procured from $\mathrm{QReC}^{\mathrm{TM}}$ chemicals Co Ltd. The chemical structure is illustrated in Figure 1. First, $1000 \mathrm{mg} / \mathrm{L}$ stock solution was prepared by dissolving an appropriate amount of dye molecules in demineralized water in a $1 \mathrm{~L}$ standard flask. From stock solution, working solution was prepared by diluting the mother solution with appropriate distilled water.

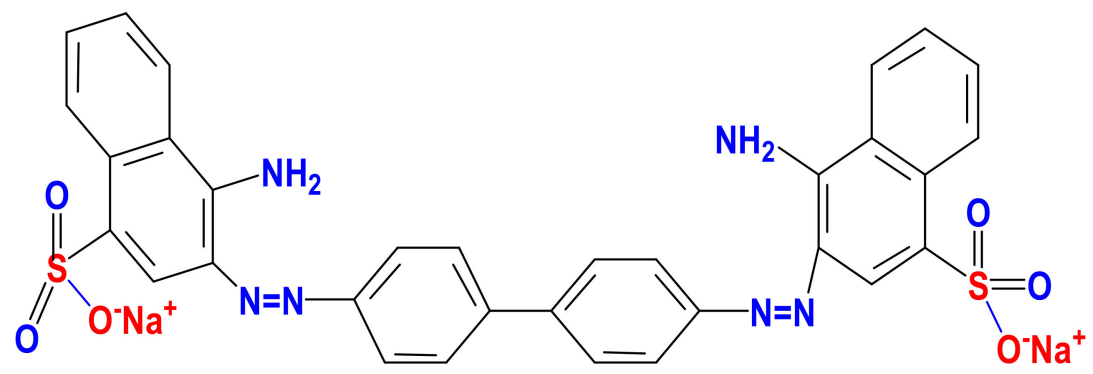

Figure 1. Structure of Congo Red (CR) dye. 


\subsection{Adsorbent Preparation}

The durian fruit peels were collected from the local area of Johor city, Malaysia. Before being processed, the durian fruit peels were cut into small pieces and washed with distilled water to remove the adhering dirt. The washed materials were oven-dried at $80^{\circ} \mathrm{C}$ for $48 \mathrm{~h}$. Thereafter, dried peels were grinded and sieved to particle size ranges from 150-200 $\mu \mathrm{m}$. About $25 \mathrm{~g}$ powered material was soaked overnight in a solution prepared from $1 \mathrm{M} \mathrm{H}_{2} \mathrm{SO}_{4}$ and $1 \mathrm{M} \mathrm{HNO}_{3}$ in the ratio of 1:1. It was then filtered and washed with distilled water to remove the residual acid content. It was further dried in an oven for $24 \mathrm{~h}$ at $80^{\circ} \mathrm{C}$ to obtain chemically activated durian peels powder, which was used for the adsorption studies.

\subsection{Characterization of Adsorbents}

The functional properties of treated and untreated durian peels powder were obtained from the Fourier Transform Infrared spectroscopy (FTIR) spectra using a Thermo Scientific NICOLET 6700 apparatus in the region of $500-4000 \mathrm{~cm}^{-1}$, at a resolution of $\pm 4.0 \mathrm{~cm}^{-1}$. The surface morphology of the treated and untreated durian peels powder was derived from the scanning electron microscopy (SEM) images by Zeiss SUPRA 55 SEM model. The scanning electron micrographs were obtained at $3 \mathrm{kV}$. The acid-treated durian powders used for the study was examined from adsorption-desorption test conducted at $77 \mathrm{~K}$ to determine the average pore diameter using micrometric model ASAP 2010 sorptometer. The pore size distribution and the surface area of the biosorbent was obtained using the Barrett-Joyner-Halenda (BJH) and Brunaure-Emmet-Teller (BET) method, respectively [30]. The Pore surface characteristics has been compared to previous studies [31-34]. The surface properties of the biosorbents are shown in Table 1.

Table 1. BET results of acid-treated durian peel compared with other adsorbents.

\begin{tabular}{ccccc}
\hline Material & $\begin{array}{c}\text { BET Surface } \\
\text { Area }\left(\mathbf{m}^{\mathbf{2}} / \mathbf{g}\right)\end{array}$ & $\begin{array}{c}\text { Pore Volume } \\
(\mathbf{c m} / \mathbf{g})\end{array}$ & $\begin{array}{c}\text { Pore Size } \\
(\AA)\end{array}$ & Reference \\
\hline Acid-treated durian fruit peel & 308.74 & 0.285 & 112.17 & Present work \\
\hline sonoenzymolysis of chitin suspension & 1.22 & $8.53 * 10^{-3}$ & 9.33 & {$[31]$} \\
\hline coffee waste $(\mathrm{CW})$ & 219.69 & 0.125 & 40.04 & {$[32]$} \\
\hline treated shrimp shell powder $(\mathrm{TSSP})$ & 66.35 & 0.0968 & 5.61 & {$[33]$} \\
\hline Triarrhena Biochar with $\mathrm{TiO}_{2}$ & 161.5 & - & 60 & {$[34]$} \\
\hline
\end{tabular}

\subsection{Experimental Design and Modelling}

The regression model equations and operational conditions of the qualitative data obtained from the adsorption study was determined using statistical analysis of the response surface methodology. Central Composite Design (CCD) design expert version 7 was used for this study to obtain the optimum process variables for the maximum adsorption of CR dyes onto modified durian peels powder. This method is most appropriate to reduce the time and variability of experimental outcomes, with improved optimized output compared to fixed optimization processes. Thirty (30) experiments were conducted using the full factorial level of the response surface consisting of six replicates number of center points on four (4) independent variables, which were $\mathrm{pH}\left(x_{1}\right)$, contact time $\left(x_{2}\right)$, initial concentration $\left(x_{3}\right)$ and temperature $\left(x_{4}\right)$. The experimental data were designed and analysed using the statistical regression model (Design Expert 6.0.10), central Composite design (CCD) (Stat-Ease, Inc., Minneapolis, MN, USA) software of the response surface methodology to investigate the effect of the interaction of the independent variables on the adsorption of CR dye on the synthesized durian peel powder. A regression model equation was developed which correlated to the response of $C R$ adsorption as a function of the independent variables, using a 2nd degree polynomial equation as illustrated in Equation (1).

$$
Y=b_{0}+\sum b_{I} x_{I}+\sum b_{i i} x^{2}+\sum b_{i j} x_{I} x_{j}+e
$$


where $Y$ denotes the predicted response, $b_{0}$ represents the constant coefficient, $b_{I}$ is the linear coefficients, $b_{i i}$ is the quadratic coefficients $b_{i j}$ depicts the interaction coefficients, and $x_{I}, x_{j}$ are the coded values of the CR dye adsorption variables.

\section{Results}

\subsection{Characterization of Treated and Untreated Durian Peel}

The SEM micrographs of both unsaturated and CR saturated durian fruit peels are shown in Figure 2. From the micrographs, some surface alterations in the unsaturated and dye saturated peel powder was observed. As shown in Figure 2a, the surface of durian fruit peels powder exhibited porous textural surface which was a predominant feature observed. However, after adsorption of CR on durian peels powder, a change in the surface morphology was noticed with the pores completely filled, indicating the adsorption of CR on the surface of the biosorbent (Figure $2 b$ ).

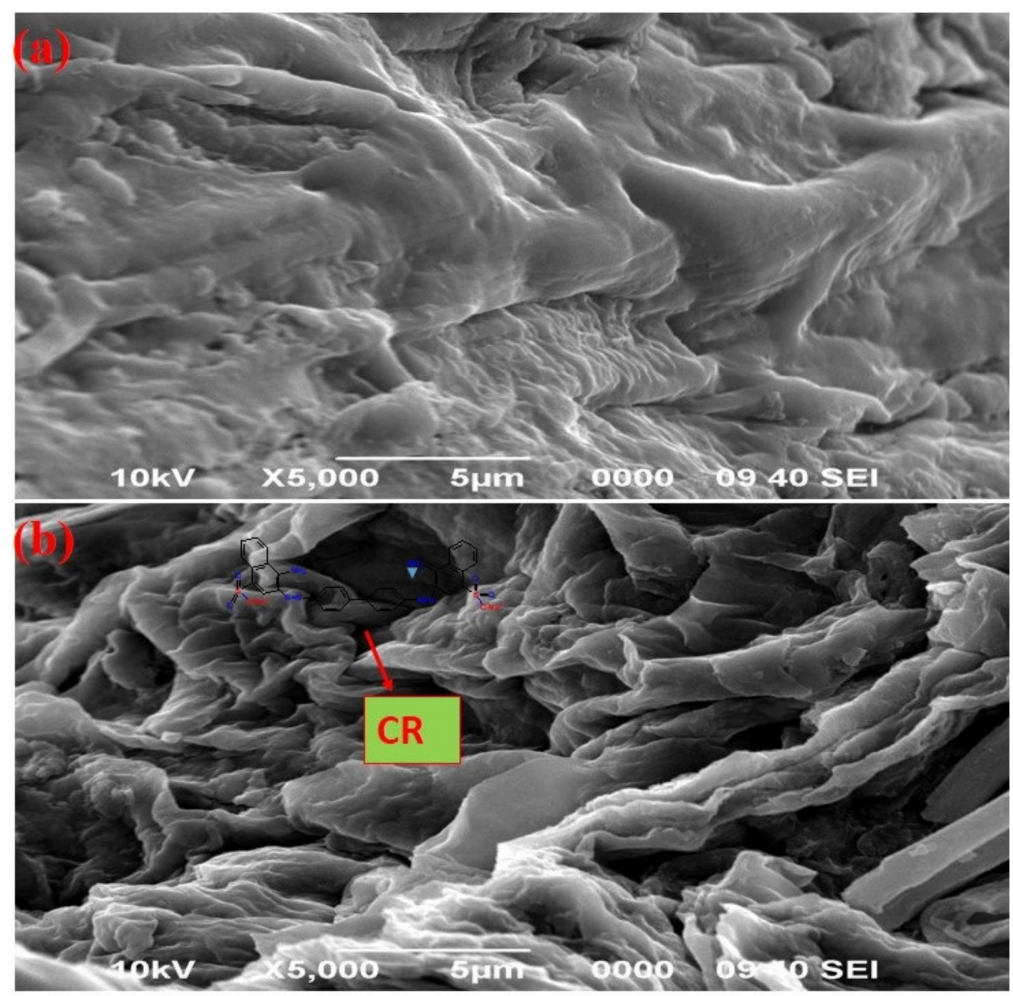

Figure 2. SEM image indicating the morphology of acid-treated durian peels (a) before and (b) after adsorption of CR at $\times 5000$ magnification.

The FTIR analysis is a very important and useful tool to describe the main functional groups present on the surface of adsorbent materials. The FTIR spectra observed before and after CR adsorption onto durian fruit peels powder are shown in Figure 3. From the FTIR spectra, a broad band appearance around $3337 \mathrm{~cm}^{-1}$ was mainly attributed to the presence of hydroxyl groups $(\mathrm{O}-\mathrm{H})$ of cellulose and lignin. The peak appeared at $2917 \mathrm{~cm}^{-1}$ was assigned to $\mathrm{C}-\mathrm{H}$ stretching of methylene groups. The strong peak at 1690 and $1647 \mathrm{~cm}^{-1}$ was assigned to the $\mathrm{C}-\mathrm{O}$ bond of the carboxylic groups present in the hemicellulose and lignocellulosic part of biosorbent. The peaks at 1453 and $1421 \mathrm{~cm}^{-1}$ could be attributed to the ring of aromatic compounds. The band at $1377 \mathrm{~cm}^{-1}$ is assigned for $\mathrm{CH}$ group of cellulose and lignin composition on the surface of the durian peels. The peak at $1183 \mathrm{~cm}^{-1}$ corresponds to asymmetric stretch of C-O-C group of ether present in lignin contained in the durian peels. The band appearance around $1037 \mathrm{~cm}^{-1}$ is assigned to $\mathrm{C}-\mathrm{O}$ stretch of primary alcohol present in lignin. In the FTIR spectra of Figure 3b, some shifts (8 to $22 \mathrm{~cm}^{-1}$ ) were observed corresponding to the $\mathrm{OH}$ and carboxylic groups indicating that these groups significantly enhanced the adsorption of dye onto the durian peels powder. 


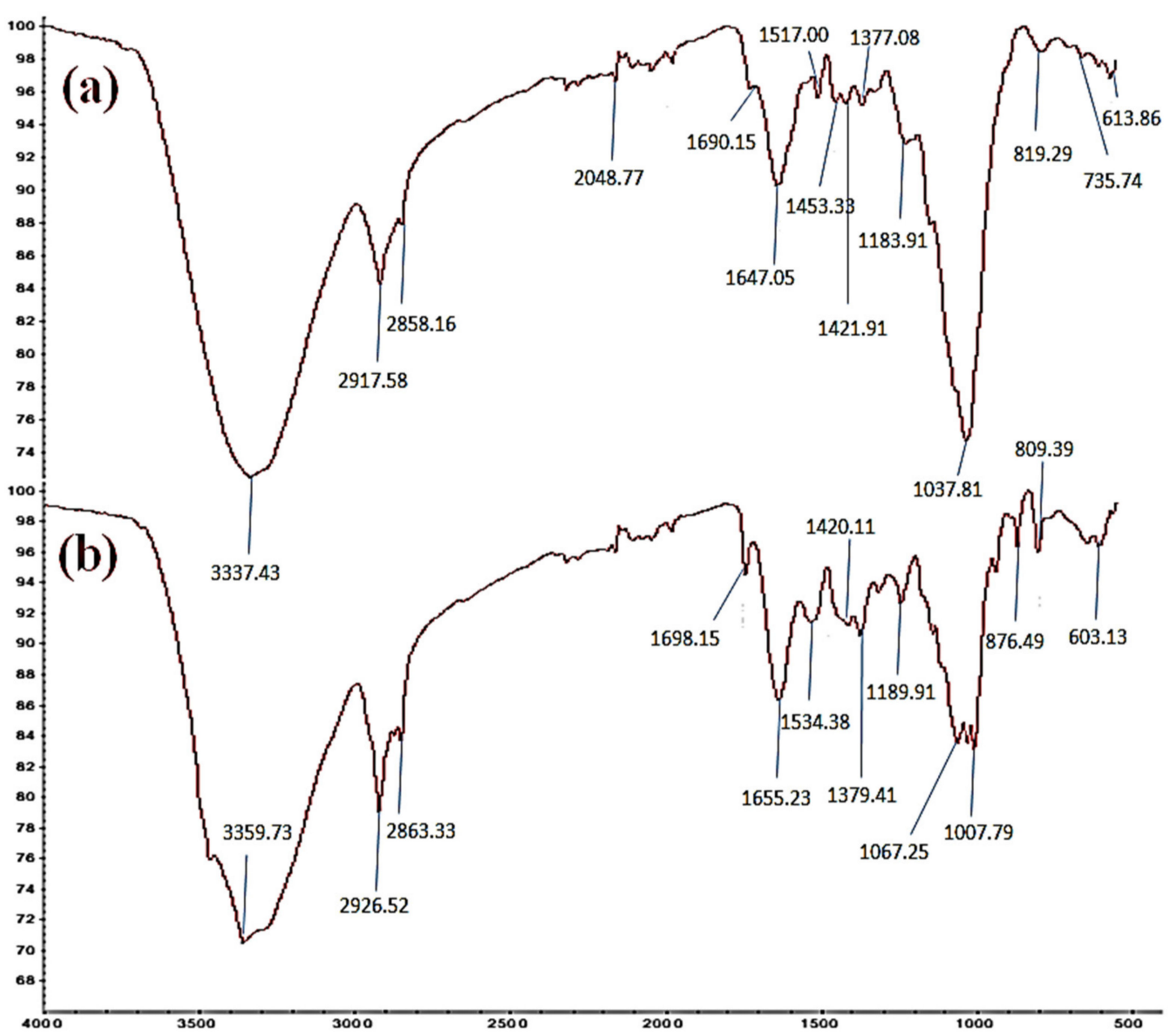

Figure 3. FTIR spectra (a) before and (b) after adsorption of CR dyes onto durian peels.

\subsection{Optimization of Dye Adsorption by Response Surface Methodology}

The development of second order polynomial regression equation for the analysis of the independent variables and its effect on the removal of CR dyes onto chemically modified durian peels powder was achieved using CCD. Statistical significance of the empirical model expressed in coded factors for the biosorption of CR dyes from aqueous solution is expressed as Equation (2). The biosorption of CR in a batch experiment was performed according to the CCD as presented in Table 2.

Table 2. Independent Variables and their coded levels for the CCD.

\begin{tabular}{cccccc}
\hline \multirow{2}{*}{ Process Variables } & \multirow{2}{*}{ Code } & Unit & \multicolumn{3}{c}{ Coded Variables } \\
\cline { 4 - 6 } & & & $-\mathbf{1}$ & $\mathbf{0}$ & $\mathbf{+ 1}$ \\
\hline $\mathrm{pH}$ & $x_{1}$ & - & 2 & 5.5 & 9 \\
\hline Contact time & $x_{2}$ & $\min$ & 10 & 105 & 200 \\
\hline Initial concentration & $x_{3}$ & $\mathrm{Mg} \mathrm{g}^{-1}$ & 25 & 212.5 & 400 \\
\hline Temperature & $x_{4}$ & ${ }^{\circ} \mathrm{C}$ & 25 & 45 & 65 \\
\hline
\end{tabular}


The observed values were compared with the predicted values evaluated from the model in Table 3.

Table 3. Matrix for the central composite design.

\begin{tabular}{|c|c|c|c|c|c|c|c|}
\hline \multirow{2}{*}{ Experiments } & \multicolumn{4}{|c|}{ Coded Variables } & \multirow{2}{*}{ Actual Value } & \multirow{2}{*}{ Predicted Value } & \multirow{2}{*}{ Residual Value } \\
\hline & $x_{1}$ & $x_{2}$ & $x_{3}$ & $x_{4}$ & & & \\
\hline 1 & 0 & 0 & 0 & 0 & 41.60 & 46.05 & -4.45 \\
\hline 2 & 2 & 0 & 0 & 0 & 63.45 & 70.41 & -6.96 \\
\hline 3 & 1 & 1 & 1 & 1 & 42.10 & 47.88 & -5.78 \\
\hline 4 & 1 & 1 & 1 & -1 & 64.30 & 69.87 & -5.57 \\
\hline 5 & -1 & 1 & 1 & -1 & 45.30 & 49.43 & -4.13 \\
\hline 6 & 1 & -1 & 1 & -1 & 68.82 & 73.88 & -5.06 \\
\hline 7 & 0 & 0 & 0 & 0 & 47.80 & 48.46 & -0.66 \\
\hline 8 & -1 & -1 & 1 & -1 & 62.50 & 70.55 & -8.05 \\
\hline 9 & 0 & 0 & 0 & 0 & 42.30 & 48.18 & -5.88 \\
\hline 10 & -1 & 1 & -1 & 1 & 62.70 & 75.38 & -12.68 \\
\hline 11 & -1 & 1 & 1 & 1 & 42.30 & 51.48 & -8.28 \\
\hline 12 & 1 & 1 & -1 & -1 & 66.50 & 76.30 & -9.80 \\
\hline 13 & 1 & 1 & -1 & 1 & 41.30 & 49.07 & -7.77 \\
\hline 14 & 0 & 0 & 0 & 0 & 68.20 & 76.35 & -8.15 \\
\hline 15 & 0 & 0 & 2 & 0 & 42.60 & 49.57 & -6.97 \\
\hline 16 & -2 & 0 & 0 & 0 & 65.60 & 74.49 & -8.89 \\
\hline 17 & -1 & -1 & 1 & 1 & 18.50 & 10.18 & 8.32 \\
\hline 18 & -1 & -1 & -1 & -1 & 78.40 & 59.45 & 18.92 \\
\hline 19 & -1 & 1 & -1 & -1 & 89.20 & 75.29 & 13.91 \\
\hline 20 & 1 & -1 & -1 & 1 & 88.61 & 75.25 & 13.36 \\
\hline 21 & -1 & -1 & -1 & 1 & 85.60 & 69.53 & 16.07 \\
\hline 22 & 0 & 0 & 0 & -2 & 82.30 & 71.10 & 11.20 \\
\hline 23 & 0 & 0 & 0 & 0 & 67.60 & 60.90 & 6.70 \\
\hline 24 & 0 & 2 & 0 & 0 & 87.54 & 66.97 & 20.57 \\
\hline 25 & 1 & -1 & -1 & -1 & 86.20 & 81.20 & 5.00 \\
\hline 26 & 0 & 0 & 0 & -2 & 95.20 & 94.38 & 0.82 \\
\hline 27 & 0 & 0 & -2 & 0 & 85.60 & 83.20 & 2.40 \\
\hline 28 & 0 & 0 & 0 & 0 & 95.70 & 94.91 & 0.79 \\
\hline 29 & 0 & -2 & 0 & 0 & 89.20 & 86.40 & 2.80 \\
\hline 30 & 1 & -1 & 1 & 1 & 68.90 & 61.20 & 7.70 \\
\hline
\end{tabular}

The plot of the normal \% probability and studentized residual for the adsorption of CR on modified durian peels powder is shown in Figure 4.

The plot of normal probability is indicated through a straight line, determining whether the residuals follow a normal distribution. It was revealed in Figure 4 that the residuals fall within a straight line, in which case, response transformation is not required [35]. The coefficient of determination of the $\left(\mathrm{R}^{2}=0.8183\right)$ obtained in the study was greater than 0.80 [36], suggesting that $R^{2}$ should be at least 0.80 for a good fit of a model. The adequate precision (AP) ratio of the model (9.302) for the biosorption of CR indicated adequacy of the signal for the model. The value of AP higher than 4 is desirable, and confirms that the predicted model can sufficiently navigate the design space as defined by the CCD [37]. The value of AP indicates better precision of the experiment carried out and the reliability of prediction. The determination coefficients $R^{2}(0.8183)$ and adjusted $R^{2}$ $\mathrm{R}^{2}$ adj $(0.6487)$ of the quadratic model indicated good agreement the experimental values and the predicted values of the model as illustrated in Equation (2). The analysis indicated that the independent process variables consisting of $\mathrm{pH}$, contact time, initial concentration and temperature were significant factors with either a positive or negative effect on the percentage removal of dye (Table 4). 


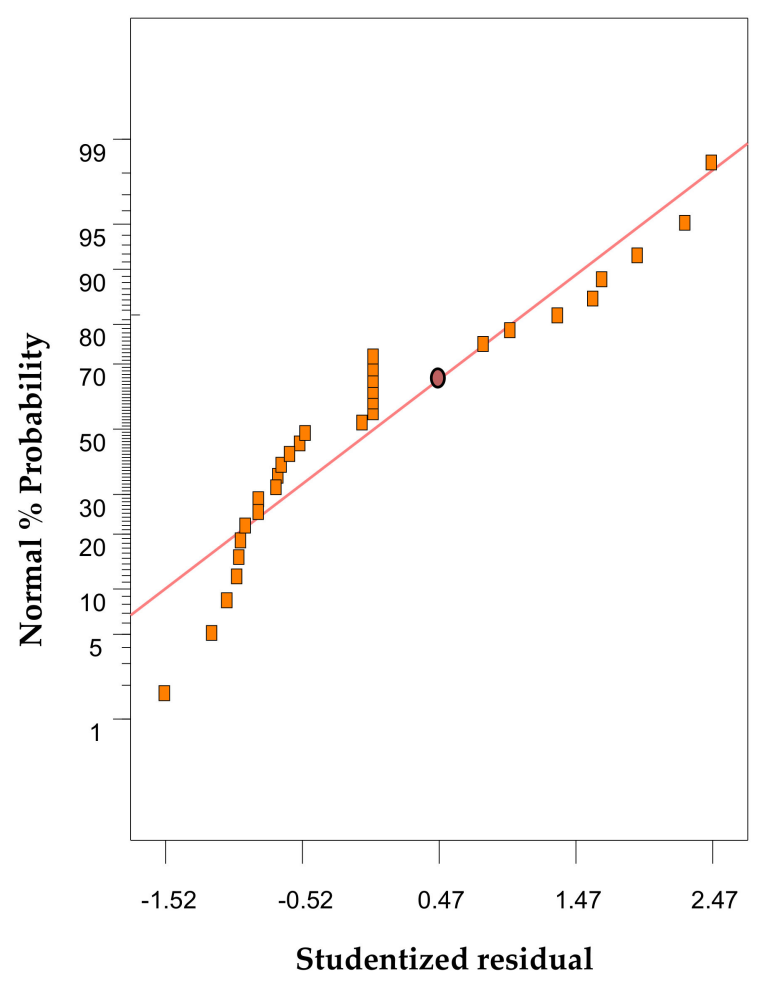

Figure 4. Plot of predicted value versus observed value of $\% C R$.

Table 4. ANOVA of response surface quadratic model for biosorption of CR.

\begin{tabular}{cccccc}
\hline Source & Sum of Squares & Degree of Freedom & Mean Square & F-Value & $p$-Value \\
\hline Model & $11,287.19$ & 14 & 806.23 & 4.82 & 0.0023 \\
\hline$x_{1}$ & 3642.53 & 1 & 3642.53 & 21.80 & 0.0003 \\
\hline$x_{2}$ & 2.604 & 1 & 2.604 & 1.56 & 0.9969 \\
\hline$x_{3}$ & 3.66 & 1 & 3.66 & 0.022 & 0.8843 \\
\hline$x_{4}$ & 55.24 & 1 & 55.24 & 0.33 & 0.5739 \\
\hline$x_{1}{ }^{2}$ & 6250.80 & 1 & 6250.80 & 37.41 & $<0.0001$ \\
\hline$x_{2}{ }^{2}$ & 680.89 & 1 & 680.89 & 4.07 & 0.0618 \\
\hline$x_{3}{ }^{2}$ & 1061.56 & 1 & 1061.56 & 6.35 & 0.0235 \\
\hline$x_{4}{ }^{2}$ & 1675.65 & 1 & 1675.65 & 10.03 & 0.0064 \\
\hline$x_{1} x_{2}$ & 5.61 & 1 & 5.61 & 0.034 & 0.0085 \\
\hline$x_{1} x_{3}$ & 8.556 & 1 & 8.556 & 5.12 & 0.0499 \\
\hline$x_{1} x_{4}$ & 8.02 & 1 & 8.02 & 0.048 & 0.0082 \\
\hline$x_{2} x_{3}$ & 2.15 & 1 & 2.15 & 0.013 & 0.9111 \\
\hline Residual & 2506.57 & 15 & 167.10 & & \\
\hline & & & & &
\end{tabular}

$$
\begin{gathered}
Y=+95.20+12.32 x_{1}-0.01 x_{2}+0.39 x_{3}+1.52 x_{4}-15.1 x_{1}{ }^{2}-4.98 x_{2}{ }^{2}-6.22 x_{3}{ }^{2}-7.84 x_{4}{ }^{2}-0.59 x_{1} x_{2} \\
+0.023 x_{1} x_{3}+0.71 x_{1} x_{4}-0.70 x_{2} x_{3}+0.37 x_{2} x_{4}-0.62 x_{3} x_{4}
\end{gathered}
$$

The effectiveness of the predictive ability of the model was found within the desirable correlation coefficient of $R^{2}$ value of (0.9999), which indicated qualitative agreement between the predicted values and experimental values (Table 5). 
Table 5. Model validation of optimum operational parameters and response.

\begin{tabular}{|c|c|c|c|c|c|c|c|}
\hline \multirow{2}{*}{ Desirability } & \multirow{2}{*}{$x_{1}$} & \multirow{2}{*}{$x_{2}$} & \multirow{2}{*}{$x_{3}$} & \multirow{2}{*}{$x_{4}$} & \multicolumn{2}{|c|}{ \%CR Removal } & \multirow{2}{*}{ Error } \\
\hline & & & & & Actual & Predicted & \\
\hline 0.9999 & 5.5 & 105 & 212.50 & 45 & 95.70 & 94.91 & 0.79 \\
\hline
\end{tabular}

Interactive Effect of Two Independent Variables

The 3D response surface indicating percentage removal of CR dyes versus the interactive effect of the independent variables is shown in Figure 5. The 3D plots represent the effect of the interaction of two operational factors with the other variables fixed at zero levels. Figure 5a shows the interaction between $\mathrm{pH}$ and time (initial concentration and temperature was fixed at zero level). As can be observed, the maximum dye biosorption was achieved around $\mathrm{pH}$, and there was rapid removal of dye within 105 min contact time and a low increase was achieved after this period. This can be attributed to a decrease in available sites as they become saturated with dye molecules [38]. Figure $5 b$ denotes the interaction between $\mathrm{pH}$ and initial concentration (contact time and temperature was fixed at zero level). The maximum biosorption of dye was in the $\mathrm{pH}$ range of 4.0-6.0. It was indicated that percent dye removal was maximum in acidic conditions and reached maximum at five, while in alkaline $\mathrm{pH}$, a decrease in the adsorption of $\mathrm{CR}$ dye onto durian surface was achieved [39]. Biosorption increased when the initial concentration was increased in acidic $\mathrm{pH}$ due to presence of active functional groups such as carboxyl, which was positively charged due to protonation on the exposed biosorbent surface, and subsequently attracted to the negatively charged CR dye molecules. As a result, the binding efficiency increased due to the electrostatic interaction between positively charged surface binding sites and the negatively charged dye molecules [40]. Figure 5c depicts the effect of the interaction of $\mathrm{pH}$ and temperature (contact time and initial concentration was fixed at zero level). As per the result obtained in Figure $5 b$, maximum biosorption of dye was obtained as the temperature increased from $45^{\circ} \mathrm{C}$. The increase in biosorption may be attributed to the increased penetration of dyes within the micropores. Figure $5 \mathrm{~d}$ revealed the effect of the interaction of contact time and initial concentration $(\mathrm{pH}$ and temperature was fixed at zero level). The percent removal of $C R$ was rapid in the first $30 \mathrm{~min}$, after which the rate of biosorption became slow. This may be explained as a result of rapid adsorption on the outer surface of the biosorbent, followed by slower adsorption within the micropores [35]. Maximum biosorption, according to the 3D response plot, was obtained at a lower $\mathrm{pH}$ and higher contact time and initial concentration and temperature. The optimum adsorption of CR (95.2\%) was achieved at the operational conditions of $\mathrm{pH}$, contact time, initial concentration and temperature at corresponding values of 5.5, $105 \mathrm{~min}, 212.5 \mathrm{mg} \mathrm{g}^{-1}$ and $45^{\circ} \mathrm{C}$, respectively.

\subsection{Adsorption Kinetic Studies}

Kinetic studies provide information about the prediction of rate of adsorption and mechanism. Accordingly, to determine the rate of loading of dye on the biosorbent, batch experiments were carried out. The treated durian peel materials $(0.1 \mathrm{~g})$ were stirred with $50 \mathrm{~mL}$ of solution containing the CR dye $\left(100 \mu \mathrm{g} \mathrm{mL}^{-1}\right)$ at temperature intervals of 10 , 20, 30, 40, 60, 90, 120, 180 and $200 \mathrm{~min}$. The dynamics of the adsorption process in terms of the order and the rate constant was evaluated using the kinetic adsorption data. The process of the dye removal from an aqueous phase by any adsorbent can be explained by using kinetic models in order to examine the rate-controlling mechanism of the adsorption process, such as diffusion control, chemical reaction, and mass transfer [41]. The kinetic parameters are useful in predicting the adsorption rate, which can be used as important information in the designing and modeling of the adsorption operation. To investigate the kinetics of the biosorption of CR dye, pseudo first-order, second-order kinetic models were used. The kinetic Equations are as follows (3) and (4). 
Pseudo-first-order model:

$$
\log \left(q_{e-} q_{t}\right)=\log q_{e-} \frac{K_{1} t}{2.303}
$$

Pseudo-second-order model:

$$
\frac{t}{q_{t}}=\frac{1}{K_{2} q_{e}^{2}}+\frac{t}{q_{e}}
$$

where $k_{1}$ and $k_{2}$ are the rate constants of the pseudo-first-order and pseudo-second- order model, respectively. $q_{e}$ and $q_{t}$ represent the adsorption capacity of biosorbent at equilibrium $\left(\mathrm{mg} \mathrm{g}^{-1}\right)$ and at time $t$, respectively. The pseudo-first-order model indicates reversible adsorption phenomenon, the model signifies that the rate of adsorption is directly proportional to the difference in the saturation of concentration and the number of unoccupied sites of the adsorbate [42]. The pseudo-second-order model defines the rate of adsorption, which is directly proportional to the square of unoccupied sites. The model describes the kinetics of pollutant binding reaction of the biosorbent [41]. The parameters obtained from the kinetics models are shown in Table 6. It was indicated that a more precise fit of kinetics data was shown by the pseudo-second order model. The calculated qe values are closer to the experimental data than the calculated values of pseudo-first order model and the values of regression coefficients $\left(\mathrm{R}^{2}\right)$ are higher $(0.9917)$ than pseudo-first order kinetic model.

To examine the diffusion process of CR onto durian peel, Weber-Morris intraparticle diffusion model was studied. The linear equation for Weber-Morris diffusion model is expressed as follows in Equation (5).

$$
q_{t}=K_{i d} t^{\frac{1}{2}}+C
$$

where, $q_{t}=$ the amount of CR adsorbed $\left(\mathrm{mg} \mathrm{g}^{-1}\right)$ at time $t(\mathrm{~min}), K_{i d}=$ the diffusion rate constant $\left(\mathrm{mg} \mathrm{g}^{-1} \mathrm{~min}^{1 / 2}\right)$, and $\mathrm{C}=$ constant $\left(\mathrm{mg} \mathrm{g}^{-1}\right)$.

The value of $K_{i d}, C$ and $\mathrm{R}^{2}$ were calculated from the gradient of plot $q_{t} \mathrm{Vs} . t^{1 / 2}$ as shown, and the related data is presented in Table 6.
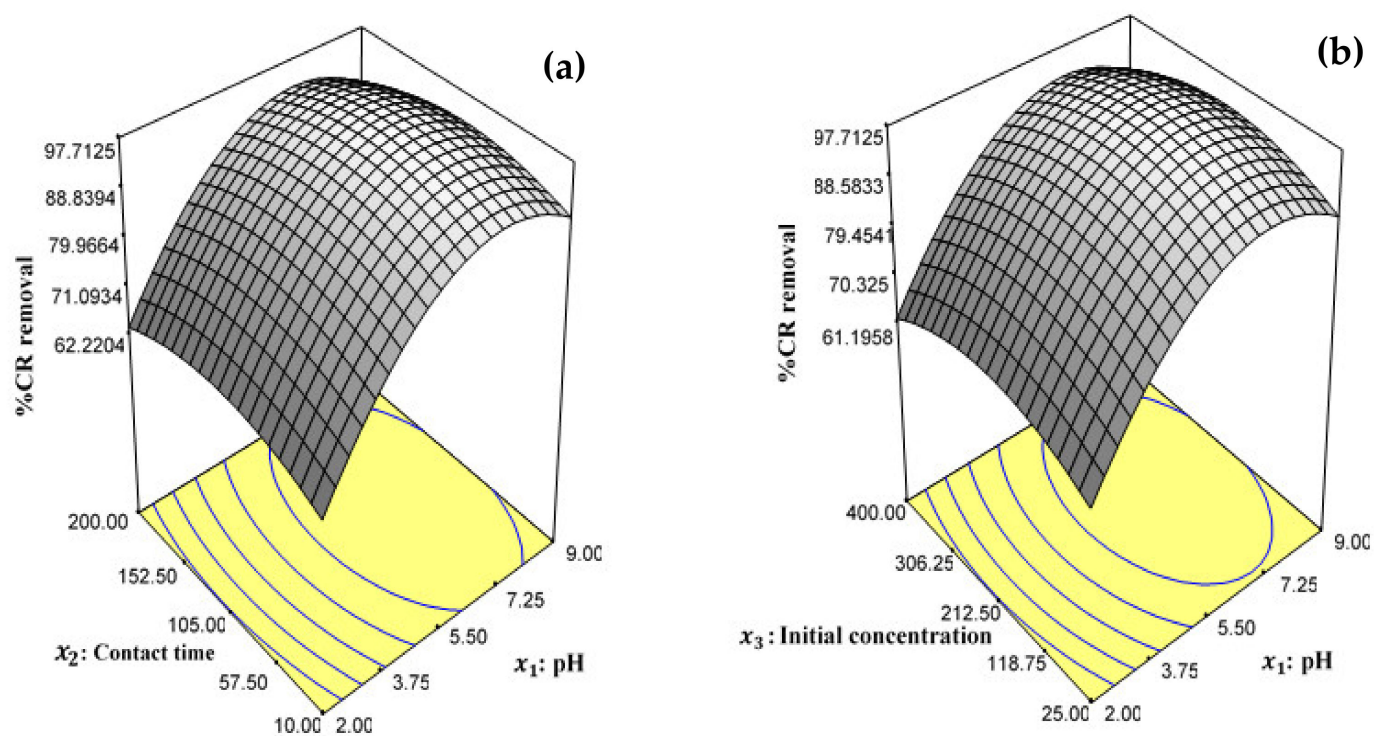

Figure 5. Cont. 

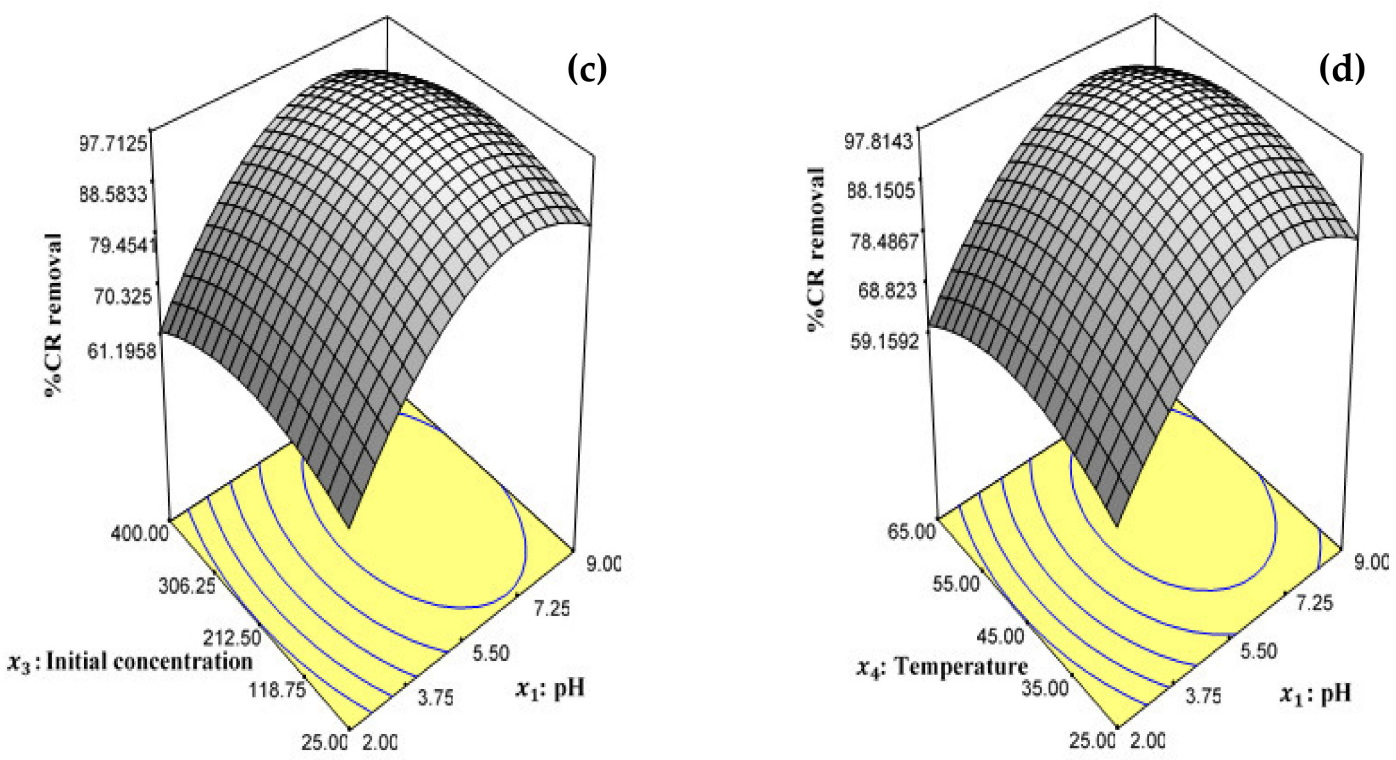

Figure 5. A 3D response surface plot (a) for the effect of $\mathrm{pH}$ and contact time (b) for the effect of $\mathrm{pH}$ and initial concentration (c) for the effect of $\mathrm{pH}$ and temperature (d) for the effect of contact time and temperature.

Table 6. Kinetic model for CR adsorption parameters onto acid-treated durian fruit peel.

\begin{tabular}{cccccc}
\hline \multicolumn{2}{c}{ Pseudo-First-Order Model } & \multicolumn{2}{c}{ Pseudo-Second-Order Model } & \multicolumn{2}{c}{ Intraparticle Diffusion Model } \\
\hline$q_{e}(\mathrm{cal})\left(\mathrm{mg} \mathrm{g}^{-1}\right)$ & 26.45 & $q_{e}(\mathrm{cal})\left(\mathrm{mg} \mathrm{g}^{-1}\right)$ & 111.11 & $K_{i d}\left(\mathrm{~g} \mathrm{mg}^{-1} \mathrm{~min}^{-1 / 2}\right)$ & 11.814 \\
\hline$K_{1}\left(\mathrm{~min}^{-1}\right)$ & 0.0274 & $K_{2}\left(\mathrm{~g} \mathrm{mg}^{-1} \mathrm{~min}^{-1}\right)$ & 0.0068 & $\mathrm{C}$ & $\mathrm{R}^{2}$ \\
\hline $\mathrm{R}^{2}$ & 0.9701 & $\mathrm{R}^{2}$ & 0.9917 & 0.950 & 0.8241 \\
\hline
\end{tabular}

The result revealed that there was multi-linearity for CR dye sorption onto durian peel powder, indicating that more than one rate determining steps was involved in the sorption process. Firstly, linear section indicated external diffusion of dye (CR) onto the durian peel surface. Moreover, second linear portion illustrated the diffusion (intra-particle) of CR, as a slowed process. On the other hand, the plot shown in Figure 6c. illustrates that there are few factors playing a significant role in the sorption process due to the multi-linearity correlation. The deviation in line where it does not pass through the origin, indicates that in the adsorption process the film diffusion and intraparticle diffusion were involved [43].

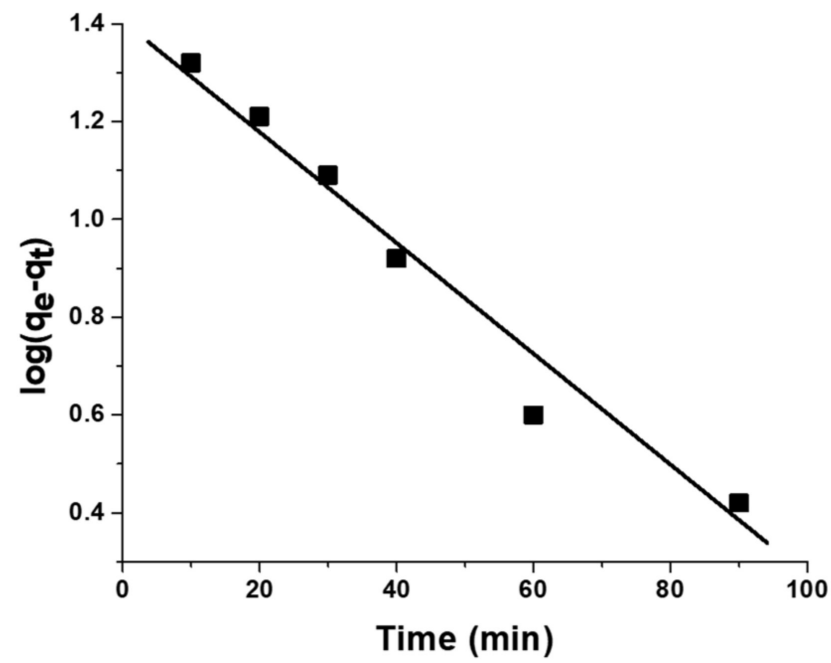

Figure 6. Cont. 

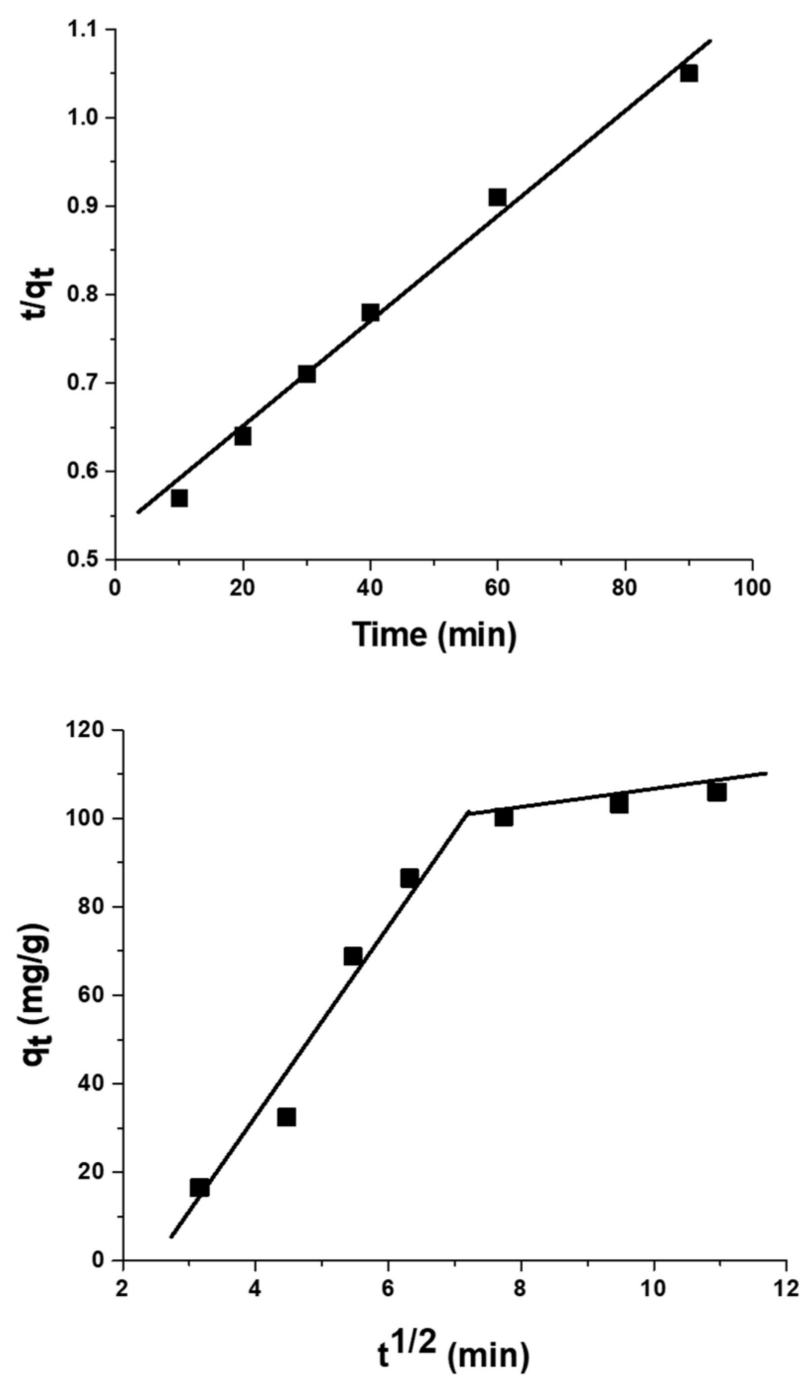

Figure 6. Adsorption kinetics (a) pseudo-first-order (b) pseudo-first-order (c) intraparticle diffusion model for the adsorption of CR dye onto acid-treated durian peels (adsorbent mass: $0.1 \mathrm{~g}$, agitation: $200 \mathrm{rpm}$, dye concentration: $100 \mathrm{mg} \mathrm{L}^{-1}$ ).

\subsection{Adsorption Isotherm Studies}

The adsorption data at equilibrium for a wide range of adsorbate concentrations are well described by various models of adsorption isotherm, such as the Langmuir, Freundlich and Temkin models. The Langmuir isotherm model assumes that adsorption occurs on different functional group sites of the adsorbent with no interaction between the adsorbed species, and that each site can accommodate many molecules (homogeneous adsorption) with the same enthalpy sorption, independent of surface coverage. The model is shown in a linear form according to Equation (6):

$$
\frac{C_{e}}{q_{e}}=\frac{1}{q_{m} b}+\frac{C_{e}}{q_{m}}
$$

where $C_{e}$ denotes equilibrium concentration in $(\mathrm{mg} / \mathrm{L}), q_{e}$ represents the amount of biosorption of dye in $(\mathrm{mg} / \mathrm{g})$. The biosorption capacity and energy of adsorption are represented by the Langmuir constants, $q_{m}$ and $b$, respectively. The value of $q_{m}$ and $b$ are obtained from the intercept and slope of the linearized plot $C_{e} / q_{e}$ against $C_{e}$, respectively. The nature of 
the adsorption is expressed in terms of a dimensionless coefficient known as the separation coefficient $\left(R_{L}\right)$ according to Equation (7).

$$
R_{L}=\frac{1}{1+b C_{o}}
$$

The $R_{L}$ values $\left(R_{L}=0\right)$ indicates adsorption is irreversible, favorable if $\left(0<R_{L}<1\right)$, linear if $\left(R_{L}=1\right)$ or unfavorable if $\left(R_{L}>1\right)$ [44].

The Freundlich model assumes that the ratio of the amount of adsorbed solute on a mass of biosorbent to the concentration of solute is not constant at varying concentration.

The linearized form of Freundlich is given by Equation (8).

$$
\ln q_{e}=\ln K_{F}+\frac{1}{n} \ln C_{e}
$$

A plot of $\ln q_{e}$ versus $\ln C_{e}$ describes the Frendlich isotherm, where $K_{F}$ is the Freundlich constant which denotes amount of dye adsorbed on biosorbent per unit equilibrium concentration. The magnitude of $\frac{1}{n}<1$ illustrates Freundlich isotherm describing the favourability of the adsorption condition. The model parameter evaluated from (Figure $7 \mathrm{~b}$ ) indicated high $\mathrm{R}^{2}$ value of 0.9831 .

The Temkin model expresses that heat of adsorption decreases linearly due to increased surface coverage [45]. The Temkin model is according to Equation (9):

$$
q_{e}=B \ln A+B \ln A+B \ln C_{e}
$$

where $q_{e}$ denotes the equilibrium amount of adsorbate adsorbed $\left(\mathrm{mg} \mathrm{g}^{-1}\right), C_{e}$ indicates the equilibrium concentration of adsorbate $\left(\mathrm{mg} \mathrm{L}^{-1}\right), B$ constant relates to the heat of absorption and is expressed in terms of $B=\mathrm{RT} / \mathrm{b}, b$ represents the Temkin constant $(\mathrm{J}$ mol- 1$), R$ signifies the gas constant $(8.314 \mathrm{~J} / \mathrm{mol} \mathrm{K}), A$ represents the Temkin constant $\left(\mathrm{Lg}^{-1}\right) . q_{e}$ is the amount adsorbed at equilibrium (mg g-1) and $q_{m}$ and $\mathrm{b}$ is Langmuir constants related to adsorption efficiency and energy of adsorption, respectively. $K_{F}$ and $n$ are Freundlich constant. $A$ is the equilibrium binding constant $\left(\mathrm{L} \mathrm{mg}^{-1}\right)$. The slope $(B)$ and intercept $(B \ln A)$ are derived from the plot of $q_{e}$ against $\ln C_{e}$. $\mathrm{R}^{2}$ value of 0.9304 was obtained from the Temkin model.

The obtained experimental data is presented in Table 7.

From the result evaluated from (7), the value of $R_{L}=0.076$ revealed favourable adsorption of CR on the biosorbent. The Langmuir model (Figure 7a) of the biosorption of CR indicated a closer proximity to unity with correlation coefficient value $\left(R^{2}=0.9989\right)$. The Freundlich model assumes that the ratio of the amount of adsorbed solute on a mass of biosorbent to the concentration of solute is not constant at varying concentration. The linearized form of Freundlich is given by Equation (8).

A plot of $\ln q_{e}$ versus $\ln C_{e}$ describes the Frendlich isotherm, where $K_{F}$ is the Freundlich constant which denotes amount of dye adsorbed on biosorbent per unit equilibrium concentration. The magnitude of $\frac{1}{n}<1$ illustrates Freundlich isotherm the favorability of the adsorption condition. The model parameter evaluated from (Figure $7 \mathrm{~b}$ ) indicated high $\mathrm{R}^{2}$ value of 0.9831 . The Temkin model expresses that heat of adsorption decreases linearly due to increased surface coverage [45]. The Temkin model is illustrated as Equation (9).

From the values of maximum adsorption efficiency $q_{m}$, it was revealed that the maximum biosorption of $\mathrm{CR}$ corresponds to a monolayer of adsorbate molecules on the surface of the modified durian peel with constant energy and with no transmission of adsorbate in the plane of the adsorbent surface. The maximum monolayer adsorption capacity $\left(q_{m}\right)$ of modified durian peels for the uptake of CR dye was compared with $\left(q_{m}\right)$ for other biosorbents available in the literature [46-50] (Table 8). 
Table 7. Adsorption isotherm limits for CR adsorption onto acid-treated durian fruit peel.

\begin{tabular}{cccccc}
\hline \multicolumn{2}{c}{ Langmuir Isotherm } & \multicolumn{2}{c}{ Freundlich Isotherm } & \multicolumn{2}{c}{ Temkin Isotherm } \\
\hline$q_{m}\left(\mathrm{mg} \mathrm{g}^{-1}\right)$ & 107.52 & $K_{F}\left(\mathrm{mg} / \mathrm{g}(\mathrm{L} / \mathrm{mg})^{1 / \mathrm{n}}\right)$ & 73.46 & $A\left(\mathrm{~L} \mathrm{mg}^{-1}\right)$ & 18.620 \\
\hline$b\left(\mathrm{~L} \mathrm{mg}^{-1}\right)$ & 0.0602 & $n$ & 1.717 & $B$ & 28.219 \\
\hline $\mathrm{R}^{2}$ & 0.9989 & $\mathrm{R}^{2}$ & 0.9831 & $\mathrm{R}^{2}$ & 0.9304 \\
\hline
\end{tabular}
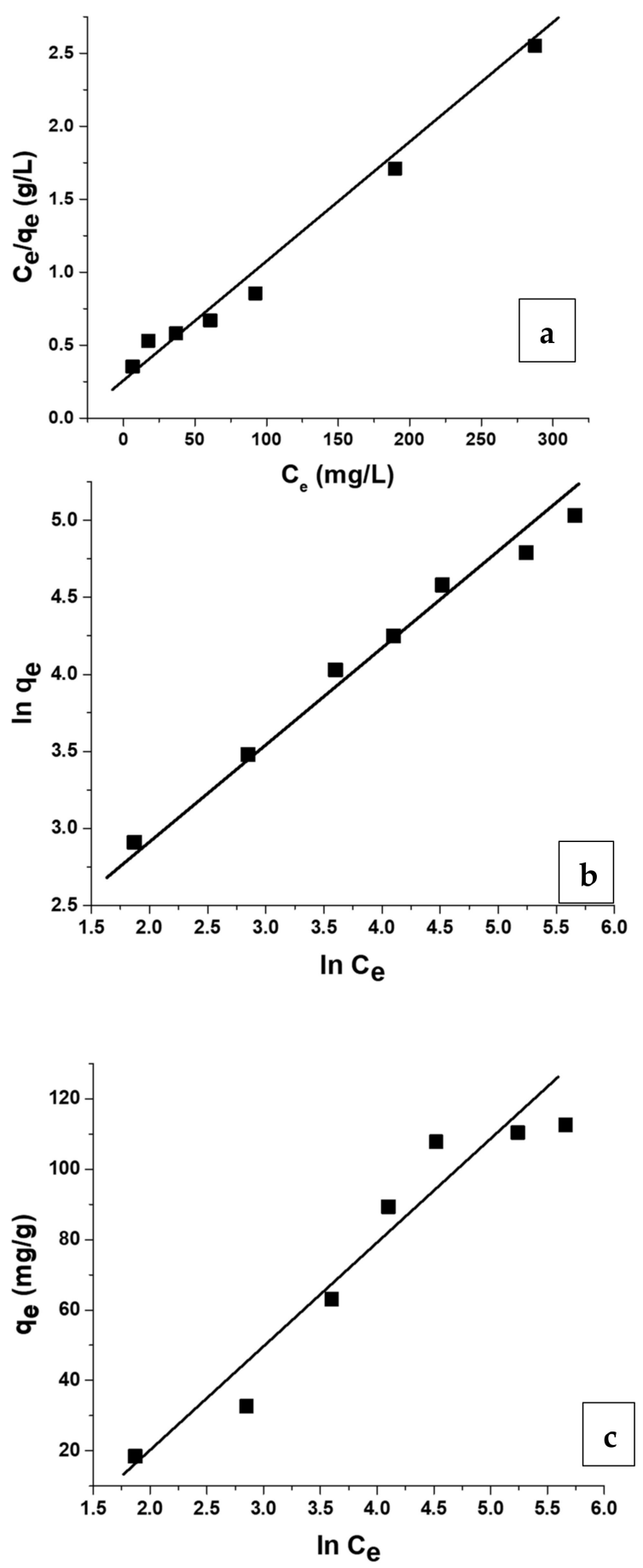

Figure 7. Adsorption Isotherm (a) Langmuir (b) Freundlich (c) Temkin model for the adsorption of CR dye onto acid-treated durian peels (adsorbent mass: $0.1 \mathrm{~g}$, agitation: $200 \mathrm{rpm}$, contact time: $105 \mathrm{~min}$, dye concentration: $200 \mathrm{mg} \mathrm{L}^{-1}$ ). 
Table 8. Comparison of maximum adsorption capacity for CR by another adsorbent.

\begin{tabular}{ccc}
\hline Adsorbent & Maximum Adsorption Capacity (mg/g) & References \\
\hline Egg shell membrane & 117.65 & {$[46]$} \\
\hline Eichhornia crassipes biomass & 14.49 & {$[47]$} \\
\hline Myrtus communis (AC-MC) & 19.23 & {$[48]$} \\
\hline pomegranate (AC-PG) & 10.00 & {$[48]$} \\
\hline acid-treated pinecone & 40.19 & {$[49]$} \\
\hline Pinus radiata cone biomass & 0.47 & {$[50]$} \\
\hline Acid-treated durian fruit peel & 105.92 & Present work \\
\hline
\end{tabular}

\subsection{Thermodynamic Parameter}

Thermodynamic parameters for the adsorption process of $\mathrm{CR}$ dye removal, including Gibbs free energy change $\left(\Delta \mathrm{G}^{\circ}\right)$, entropy change $\left(\Delta \mathrm{S}^{\circ}\right)$ and enthalpy change $\left(\Delta \mathrm{H}^{\circ}\right)$, were calculated using the following Equations:

$$
\begin{gathered}
\Delta \mathrm{G}^{\circ}=-R T \ln \mathrm{K}_{c} \\
\ln \mathrm{K}_{c}=\frac{\Delta \mathrm{S}^{\circ}}{R}-\frac{\Delta \mathrm{H}^{\circ}}{R T}
\end{gathered}
$$

where, $T(K)=$ the absolute temperature, $R=\left(8.314 \mathrm{~J} \mathrm{~mol}^{-1} \mathrm{~K}^{-1}\right)$ which is universal gas constant and $K_{c}=$ the distribution coefficient.

The nature of the interaction between adsorbate molecules and adsorbent can be classified according to the magnitude of the enthalpy change $\left(\Delta \mathrm{H}^{\circ}\right)$ and entropy change $\left(\Delta \mathrm{S}^{\circ}\right)$. The evaluation of enthalpy $\left(\Delta \mathrm{H}^{\circ}\right)$ and entropy $\left(\Delta \mathrm{S}^{\circ}\right)$ were calculated from the slope and intercept of $\ln K_{c}$ vs $1 / \mathrm{T}$ plot at different experimental temperatures as shown in Figure 8.

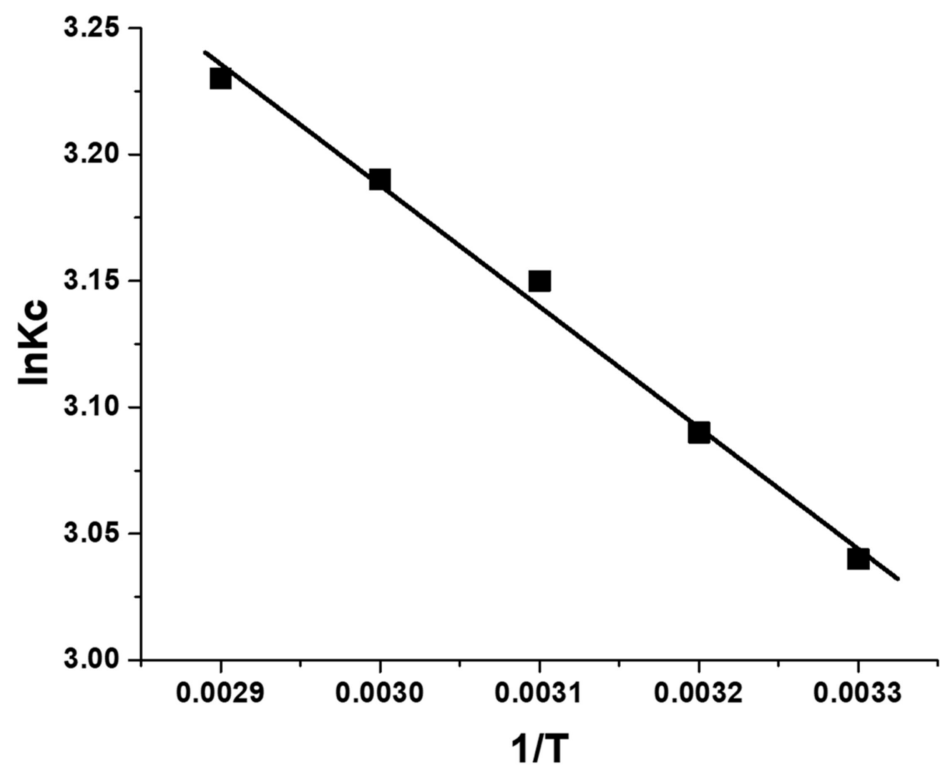

Figure 8. Vant Hoff's plot for the biosorption of CR dyes.

It can be seen from Table 9 that $\Delta \mathrm{G}^{\circ}$ values differ from -7.531 to $-9.076 \mathrm{kJmol}^{-1}$ as the temperature increases from 298 to $338 \mathrm{~K}$ and the -ve value of $\Delta \mathrm{G}^{\circ}$ could be attributed to the feasibility and spontaneity of adsorption process with greater sorption performance of $\mathrm{CR}$ on acid-treated durian peels powder. The decreasing value of Gibbs free energy $\left(\Delta \mathrm{G}^{\circ}\right)$ with increasing temperature indicates that the degree of spontaneity of the adsorption 
process increases with increasing temperature. Generally, changes in adsorption enthalpy denoting physiosorption ranges from -20 to $40 \mathrm{~kJ} / \mathrm{mol}$ and chemisorption ranges between -400 and $-80 \mathrm{~kJ} / \mathrm{mol}$ [51]. Experimental data shows that positive $\Delta \mathrm{H}^{\circ}(9.219 \mathrm{~kJ} / \mathrm{mol})$ indicates endothermic process and physical adsorption. Hence, the result revealed that physical forces were involved in adsorption of $\mathrm{CR}$ onto durian peels powder. Furthermore, the positive values of $\Delta S^{\circ}(38.477 \mathrm{Kj} / \mathrm{molK})$ suggest increased disorderliness of solidliquid interfacial interaction during the adsorption process of dye (CR) onto durian peels biosorbent [52]. The magnitude and sign of $\Delta S^{\circ}$ gives an indication whether the adsorption process is an associative or dissociative mechanism. A positive $\Delta S^{\circ}$ value indicates that the adsorption procedure comprises a dissociative mechanism.

Table 9. Thermodynamic studies for $C R$ adsorption onto acid-treated durian fruit peel.

\begin{tabular}{cccc}
\hline $\boldsymbol{\Delta}^{\circ} \mathbf{H}(\mathbf{K j} / \mathbf{m o l})$ & $\boldsymbol{\Delta}^{\circ} \mathbf{S}(\mathbf{K j} / \mathbf{m o l K})$ & Temperature (K) & $\boldsymbol{\Delta}^{\circ} \mathbf{G ~ ( K j / m o l )}$ \\
\hline & & 298 & -7.531 \\
\cline { 2 - 3 } 9.219 & \multirow{3}{*}{38.477} & 308 & -7.912 \\
\cline { 2 - 3 } & & 318 & -8.328 \\
\cline { 2 - 3 } & & 328 & -8.699 \\
\hline
\end{tabular}

\subsection{Biosorption Mechanism}

The mechanism for the adsorption of $\mathrm{CR}$ dyes onto modified durian peels is illustrated Figure 9. The removal mechanism of biosorption of CR dyes has essentially been subjected to electrostatic interactions and hydrogen bonding. According to FTIR spectra, different functional groups such as hydroxyl, ester, ether and carboxylic groups were predominant on the surface of the durian fruit peels. From the FTIR spectra, some shift $\left(8\right.$ to $22 \mathrm{~cm}^{-1}$ ) was observed in position of hydroxyl and carboxylic groups after adsorption of CR dye suggesting that these groups were mainly responsible for the adsorption of $\mathrm{CR}$ dye onto the surface of durian peels.

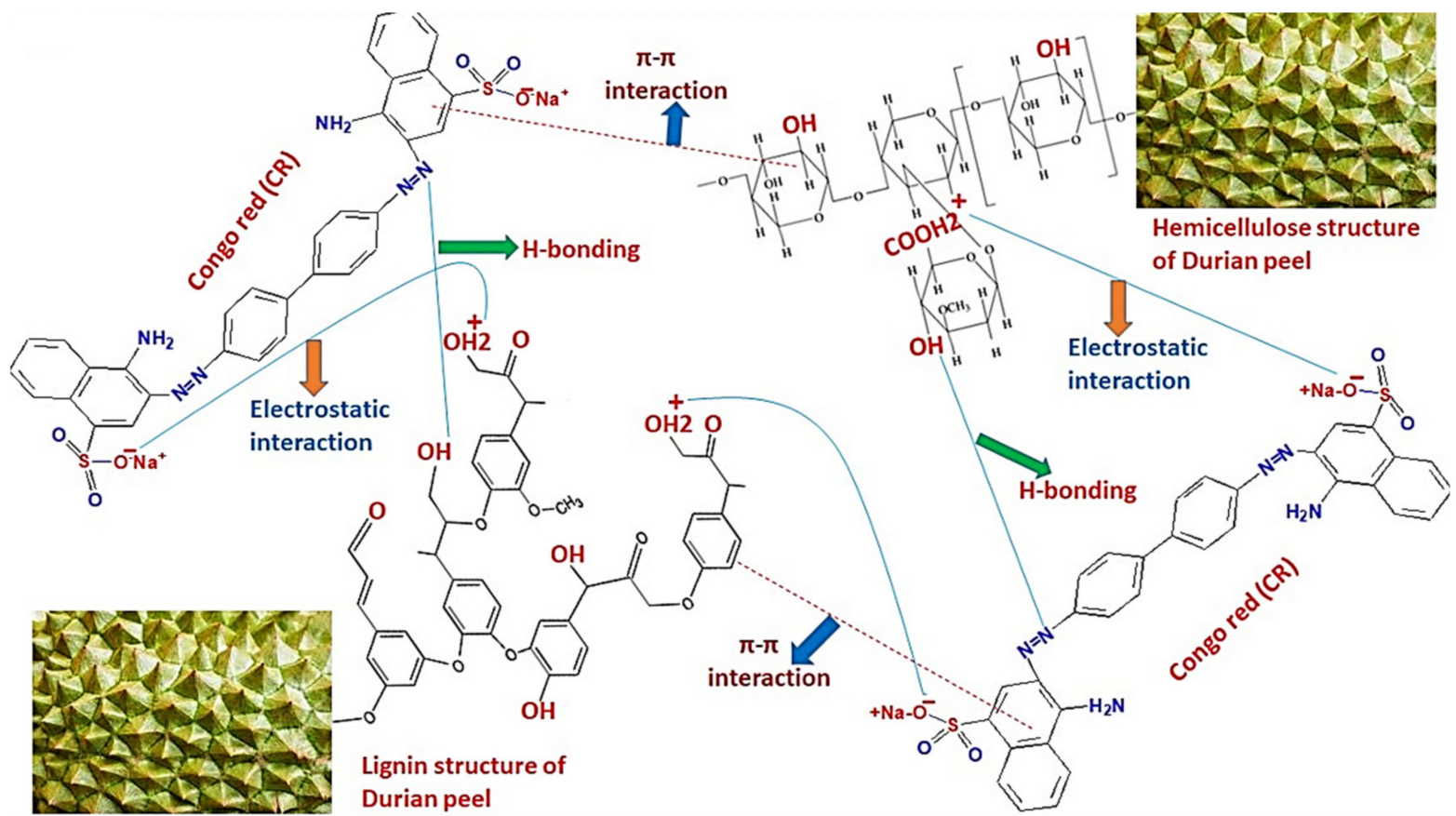

Figure 9. The mechanism for the adsorption of CR dyes onto modified durian peels. 
The biosorption system depends on the active sites which also depends on the $\mathrm{pH}$ of the adsorbate. The surface interaction of dye molecules on active sites of the biosorbent is greatly influenced by the solution $\mathrm{pH}$ [53]. In this study, maximum adsorption capacity of $\mathrm{CR}$ dyes on modified durian peels were observed under acidic solution ( $\mathrm{pH}$ 5). In acidic $\mathrm{pH}$, surface charge of durian fruit peels was positively charged and more protonated sites $\left(\mathrm{H}^{+}\right)$were present on the surface resulting in increased electrostatic interaction between the positively charged surface and negatively charged CR dye molecules [54]. Furthermore, in basic $\mathrm{pH}$, the surface of durian peels contained more hydroxyl ions $\left(\mathrm{OH}^{-}\right)$, which resulted in the deprotonation of carboxylic and hydroxyl groups. This may cause a decrease in electrostatic interaction between surface charge of durian peel and negatively charged CR dye molecules [55]. Aside from electrostatic interaction, H-bonding (between electronegative atom and $\mathrm{H}$-atom) and pi-pi interaction also played a significant role in CR adsorption onto the surface of the modified durian peels powder. According to isotherm studies, experimental data were better fitted to the Langmuir model for the adsorption of $\mathrm{CR}$ dyes molecules on the surface of the biosorbent, which implies that monolayer adsorption occurs on the homogeneous surface filled with localized adsorption sites. Same findings reported CR adsorption onto PEI-wheat straw and coffee waste [56,57].The biosorption of $\mathrm{CR}$ dyes investigated under different operational conditions indicated that under acidic $\mathrm{pH}$, increased adsorption efficiency was favoured through electrostatic interactions, along with hydrogen bonding which enhanced the adsorption efficiency of acid-treated durian peels for the adsorption of CR dye molecules.

\section{Conclusions}

In this study, acid-treated durian peels were prepared and investigated as a possible biosorbent for the removal of $\mathrm{CR}$ dyes in aqueous solution. The biosorption investigation was carried out as a function of $\mathrm{pH}\left(x_{1}\right)$, contact time $\left(x_{2}\right)$, initial concentration $\left(x_{3}\right)$, and temperature $\left(x_{4}\right)$. Percentage removal of $\mathrm{CR}$ dye molecules increased in acid $\mathrm{pH}$ condition as the initial concentration increased, and also as the contact time and temperature increased to a certain level. Therefore, the biosorption of $\mathrm{CR}$ was effective within the range of the investigated parameters. The optimum condition for $95.2 \%$ removal of CR was achieved at $\mathrm{pH} 5$, contact time of $105 \mathrm{~min}$ at initial concentration of $212.5 \mathrm{mg} \mathrm{g}^{-1}$ within $45^{\circ} \mathrm{C}$. The Langmuir isotherm model best described the biosorption process. The kinetic data was better fitted to the pseudo-second-order model. Overall, the thermodynamic parameters revealed that the adsorption of $\mathrm{CR}$ dyes on acid-treated durian peels powder was spontaneous, endothermic and physical forces determined the biosorption of CR. Generally, the rapid adsorption of $\mathrm{CR}$ at shorter contact time was attributed to film diffusion and intraparticle diffusion at longer adsorption time. The mechanism of biosorption was influenced by electrostatic interaction and hydrogen bonding. The high removal capacity of $\mathrm{CR}$ dyes indicted that acid-treated durian peels could be used as an alternative biosorbent for the treatment of effluents from textiles and dyeing industries.

Author Contributions: Conceptualization, A.A., M.M.H., H.P.S.A.K. and S.H.M.S.; methodology, A.A. and A.A.O.; software, H.P.S.A.K., S.H.M.S. and M.M.H.; validation, A.A.O., A.A., M.J., A.V. and M.M.H.; formal analysis, A.A., M.B.A. and A.A.O.; investigation, A.A. and S.H.M.S.; resources, A.A. and A.A.O.; data curation, A.A. and A.A.O.; writing-A.A., A.V. and A.A.O.; preparation, A.A. and A.A.O.; writing-review and editing, A.A.O., M.J., A.V. and A.A.; visualization, H.P.S.A.K., M.M.H. and M.B.A.; supervision, A.A. and M.J.; project administration, M.J., M.M.H. and A.A.O.; funding acquisition, S.H.M.S., M.B.A. and M.J. All authors have read and agreed to the published version of the manuscript.

Funding: This research was funded by (Universiti Teknologi Malaysia grant number (UTM.J.13.01/13.14/ 1/88 Jld.20 (96)) and the APC was funded by International Clean Water Institute and Universiti Putra Malaysia.

Institutional Review Board Statement: Not applicable.

Informed Consent Statement: Not applicable. 
Data Availability Statement: Data is contained within the article.

Acknowledgments: Authors are thankful to Research Management Centre (RMC), Universiti Teknologi Malaysia and Universiti Putra Malaysia for providing the research facilities.

Conflicts of Interest: The authors declare no conflict of interest.

\section{References}

1. Si, J.; Yuan, T.-Q.; Cui, B.-K. Exploring Strategies for Adsorption of Azo Dye Congo Red Using Free and Immobilized Biomasses of Trametes Pubescens. Ann. Microbiol. 2014, 65, 411-421. [CrossRef]

2. Li, Z.; Hanafy, H.; Zhang, L.; Sellaoui, L.; Netto, M.S.; Oliveira, M.L.; Seliem, M.K.; Dotto, G.L.; Bonilla-Petriciolet, A.; Li, Q. Adsorption of Congo Red and Methylene Blue Dyes on an Ashitaba Waste and a Walnut Shell-Based Activated Carbon from Aqueous Solutions: Experiments, Characterization and Physical Interpretations. Chem. Eng. J. 2020, 388, 124263. [CrossRef]

3. Oyekanmi, A.A.; Ahmad, A.; Hossain, K.; Rafatullah, M. Adsorption of Rhodamine B Dye from Aqueous Solution onto Acid Treated Banana Peel: Response Surface Method-Ology, Kinetics and Isotherm Studies. PLoS ONE 2019, 14, e0216878. [CrossRef] [PubMed]

4. Oyekanmi, A.A.; Ahmad, A.; Hossain, K.; Rafatullah, M. Statistical Optimization for Adsorption of Rhodamine B Dye from Aqueous Solutions. J. Mol. Liq. 2019, 281, 48-58. [CrossRef]

5. Iqbal, M.M.; Imran, M.; Hussain, T.; Naeem, M.A.; Al-Kahtani, A.A.; Shah, G.M.; Ahmad, S.; Farooq, A.; Rizwan, M.; Majeed, A.; et al. Effective Sequestration of Congo Red Dye With ZnO/Cotton Stalks Biochar Nanocomposite: MODELING, Reusability and Stability. J. Saudi Chem. Soc. 2021, 25, 101176. [CrossRef]

6. Zhu, M.-X.; Lee, L.; Wang, H.-H.; Wang, Z. Removal of an Anionic Dye by adsorption/Precipitation Processes Using Alkaline White Mud. J. Hazard. Mater. 2007, 149, 735-741. [CrossRef]

7. Li, H.; Lin, Y.; Luo, Y.; Yu, P.; Hou, L. Relating Organic Fouling of Reverse Osmosis Membranes to Adsorption During the Reclamation of Secondary Effluents Contain-Ing Methylene Blue and Rhodamine, B. J. Hazard. Mater. 2011, 192, 490-499. [CrossRef] [PubMed]

8. Ruhane, T.; Islam, M.T.; Rahaman, S.; Bhuiyan, M.; Islam, J.M.; Newaz, M.; Khan, K.; Khan, M.A. Photo Current Enhancement of Natural Dye Sensitized Solar Cell by Optimizing Dye Extraction and Its Loading Period. Optik 2017, 149, 174-183. [CrossRef]

9. Natarajan, S.; Bajaj, H.C.; Tayade, R.J. Recent Advances Based on the Synergetic Effect of Adsorption for Removal of Dyes from Waste Water Using Photocatalytic Process. J. Environ. Sci. 2018, 65, 201-222. [CrossRef]

10. Raghu, S.; Basha, C.A. Chemical or Electrochemical Techniques, Followed by Ion Exchange, for Recycle of Textile Dye Wastewater. J. Hazard. Mater. 2007, 149, 324-330. [CrossRef]

11. Bouazizi, A.; Breida, M.; Achiou, B.; Ouammou, M.; Calvo, J.I.; Aaddane, A.; Younssi, S.A. Removal of Dyes by a New nano-TiO 2 Ultrafiltration Membrane Deposited on Low-Cost Support Prepared from Natural Moroccan Bentonite. Appl. Clay Sci. 2017, 149, 127-135. [CrossRef]

12. Moghaddam, S.S.; Moghaddam, M.A.; Arami, M. Coagulation/Flocculation Process for Dye Removal Using Sludge from Water Treatment Plant: Optimization through Response Surface Methodology. J. Hazard. Mater. 2010, 175, 651-657. [CrossRef]

13. Adeleke, A.O.; Latiff, A.A.A.; Daud, Z.; Daud, N.F.M.; Aliyu, M.K. Heavy Metal Removal from Wastewater of Palm Oil Mill Using Developed Activated Carbon from Coconut Shell and Cow Bones. Key Eng. Mater. 2017, 737, 428-432. [CrossRef]

14. Adeleke, O.A.; Latiff, A.A.A.; Saphira, M.R.; Daud, Z.; Ismail, N.; Ahsan, A.; Ab Aziz, N.A.; Al-Gheethi, A.; Kumar, V.; Fadilat, A.; et al. Principles and Mechanism of Adsorption for the Effective Treatment of Palm Oil Mill Effluent for Water Reuse. In Nanotechnology in Water and Wastewater Treatment; Elsevier: Amsterdam, The Netherlands, 2019; pp. 1-33. [CrossRef]

15. Oyekanmi, A.A.; Daud, Z; Daud, N.M.; Gani, P. Adsorption of Heavy Metal from Palm Oil Mill Effluent on the Mixed Media Used For the Preparation of Compo-Site Adsorbent. In MATEC Web of Conferences; EDP Sciences: Les Ulis, France, 2017; Volume 103, p. 06020. [CrossRef]

16. Wang, H.; Li, Z.; Yahyaoui, S.; Hanafy, H.; Seliem, M.K.; Bonilla-Petriciolet, A.; Dotto, G.L.; Sellaoui, L.; Li, Q. Effective adsorption of dyes on an activated carbon prepared from carboxymethyl cellulose: Experiments, characterization and advanced modelling. Chem. Eng. J. 2020, 417, 128116. [CrossRef]

17. Alouache, A.; Selatnia, A.; Sayah, H.E.; Khodja, M.; Moussous, S.; Daoud, N. Biosorption of Hexavalent Chromium and Congo Red Dye onto Pleurotus Mutilus Biomass in Aqueous Solutions. Int. J. Environ. Sci. Technol. 2021, 1-16. [CrossRef]

18. Moradi, M.; Sabzevari, M.H.; Marahel, F.; Shameli, A. Removal of Reactive Green KE-4BD and Congo Red Dyes in Textile Effluent by Natural Clinoptilolite Particles on a Biosorbent As a Cheap and Efficient Adsorbent: Experimental Design and Optimisation. Int. J. Environ. Anal. Chem. 2021, 1-19. [CrossRef]

19. Labena, A.; Abdelhamid, A.; Amin, A.; Husien, S.; Hamid, L.; Safwat, G.; Diab, A.; Gobouri, A.; Azab, E. Removal of Methylene Blue and Congo Red Using Adsorptive Membrane Impregnated With Dried Ulva fasciata and Sargassum dentifolium. Plants 2021, 10, 384. [CrossRef]

20. Banisheykholeslami, F.; Hosseini, M.; Darzi, G.N. Design of PAMAM Grafted Chitosan Dendrimers Biosorbent for Removal of Anionic Dyes: Adsorption Isotherms, Kinetics and Thermodynamics Studies. Int. J. Biol. Macromol. 2021, 177, 306-316. [CrossRef]

21. Wekoye, J.N.; Wanyonyi, W.C.; Wangila, P.T.; Tonui, M.K. Kinetic and Equilibrium Studies of Congo Red Dye Adsorption on Cabbage Waste Powder. Environ. Chem. Ecotoxicol. 2020, 2, 24-31. [CrossRef] 
22. Achour, Y.; Bahsis, L.; Ablouh, E.-H.; Yazid, H.; Laamari, M.R.; El Haddad, M. Insight into Adsorption Mechanism of Congo Red Dye onto Bombax Buonopozense Bark Activated-Carbon Using Central Composite Design and DFT Studies. Surf. Interfaces 2021, 23, 100977. [CrossRef]

23. Wanyonyi, W.C.; Onyari, J.M.; Shiundu, P.M. Adsorption of Congo Red Dye from Aqueous Solutions Using Roots of Eichhornia Crassipes: Kinetic and Equilibrium Studies. Energy Procedia 2014, 50, 862-869. [CrossRef]

24. Dawood, S.; Sen, T.K.; Phan, C. Synthesis and Characterisation of Novel-Activated Carbon from Waste Biomass Pine Cone and Its Application in the Removal of Congo Red Dye from Aqueous Solution by Adsorption. Waterairsoil Pollut. 2014, 225, 1-16. [CrossRef]

25. Ponnusamy, S.K.; Subramaniam, R. Process Optimization Studies of Congo Red Dye Adsorption onto Cashew Nut Shell Using Response Surface Methodology. Int. J. Ind. Chem. 2013, 4, 17. [CrossRef]

26. Pathania, D.; Sharma, A.; Siddiqi, Z.-M. Removal of Congo Red Dye from Aqueous System Using Phoenix Dactylifera Seeds. J. Mol. Liq. 2016, 219, 359-367. [CrossRef]

27. Ojedokun, A.T.; Bello, O.S. Kinetic Modeling of Liquid-Phase Adsorption of Congo Red Dye Using Guava Leaf-Based Activated Carbon. Appl. Water Sci. 2017, 7, 1965-1977. [CrossRef]

28. Safari, S.; Athirah, N.F.; Sunthralingam, C.; Jamaludin, J.A.; Mustaffa, R. Durian as new source of Malaysia's agricultural wealth. FFTC Agric. Policy Artic. 2018, 13, 1-6.

29. Wai, W.W.; AlKarkhi, A.F.; Easa, A.M. Comparing Biosorbent Ability of Modified Citrus and Durian Rind Pectin. Carbohydr. Polym. 2010, 79, 584-589. [CrossRef]

30. Anbia, M.; Ghaffari, A. Removal of Malachite Green from Dye Wastewater Using Mesoporous Carbon Adsorbent. J. Iran. Chem. Soc. 2011, 8, S67-S76. [CrossRef]

31. Hou, F.; Wang, D.; Ma, X.; Fan, L.; Ding, T.; Ye, X.; Liu, D. Enhanced Adsorption of Congo Red Using Chitin Suspension After Sonoenzymolysis. Ultrason. Sonochemistry 2021, 70, 105327. [CrossRef]

32. Lafi, R.; Montasser, I.; Hafiane, A. Adsorption of Congo Red Dye from Aqueous Solutions by Prepared Activated Carbon With Oxygen-Containing Functional Groups and Its Regeneration. Adsorpt. Sci. Technol. 2019, 37, 160-181. [CrossRef]

33. Zhou, Y.; Ge, L.; Fan, N.; Xia, M. Adsorption of Congo Red from Aqueous Solution onto Shrimp Shell Powder. Adsorpt. Sci. Technol. 2018, 36, 1310-1330. [CrossRef]

34. Yu, P.; Hu, T.; Chen, H.H.; Wu, F.; Liu, H. Effective Removal of Congo Red by Triarrhena Biochar Loading With TiO2 Nanoparticles. Scanning 2018, 2018, 1-7. [CrossRef] [PubMed]

35. Tanyildizi, M.Ş. Modeling of Adsorption Isotherms and Kinetics of Reactive Dye from Aqueous Solution by Peanut Hull. Chem. Eng. J. 2011, 168, 1234-1240. [CrossRef]

36. Mirhosseini, H.; Tan, C.P.; Hamid, N.; Yusof, S. Effect of Arabic Gum, Xanthan Gum and Orange Oil Contents on $\zeta$-Potential, Conductivity, Stability, Size Index and PH of Orange Beverage Emulsion. Colloids Surf. A Physicochem. Eng. Asp. 2008, 315, 47-56. [CrossRef]

37. Zhou, B.; Wang, T.; Li, C.; Fu, J.; Zhang, Z.; Song, Z.; Ma, C. Multi-Objective Optimization of the Preparation Parameters of the Powdered Activated Coke for SO2 Adsorption Using Response Surface Methodology. J. Anal. Appl. Pyrolysis 2020, 146, 104776. [CrossRef]

38. Seera, S.D.K.; Kundu, D.; Gami, P.; Naik, P.K.; Banerjee, T. Synthesis and Characterization of Xylan-Gelatin Cross-Linked Reusable Hydrogel for the Adsorption of Methylene Blue. Carbohydr. Polym. 2021, 256, 117520. [CrossRef] [PubMed]

39. Asfaram, A.; Ghaedi, M.; Ghezelbash, G.R.; Dil, E.A.; Tyagi, I.; Agarwal, S.; Gupta, V.K. Biosorption of Malachite Green by Novel Biosorbent Yarrowia Lipolytica isf7: Application of Response Surface Methodology. J. Mol. Liq. 2016, 214, 249-258. [CrossRef]

40. Al-Degs, Y.S.; El-Barghouthi, M.I.; El-Sheikh, A.H.; Walker, G.M. Effect of Solution PH, Ionic Strength, and Temperature on Adsorption Behavior of Reactive Dyes on Activated Carbon. Dyes Pigment. 2008, 77, 16-23. [CrossRef]

41. Tanzifi, M.; Hosseini, S.H.; Kiadehi, A.D.; Olazar, M.; Karimipour, K.; Rezaiemehr, R.; Ali, I. Artificial Neural Network Optimization for Methyl Orange Adsorption onto Polyaniline Nano-Adsorbent: Kinetic, Isotherm and Thermodynamic Studies. J. Mol. Liq. 2017, 244, 189-200. [CrossRef]

42. Karoui, S.; Arfi, R.B.; Mougin, K.; Ghorbal, A.; Assadi, A.A.; Amrane, A. Synthesis of Novel Biocomposite Powder for Simultaneous Removal of Hazardous Ciprofloxacin and Methylene Blue: Central Composite Design, Kinetic and Isotherm Studies Using Brouers-Sotolongo Family Models. J. Hazard. Mater. 2020, 387, 121675. [CrossRef] [PubMed]

43. Hamdaoui, O. Batch Study of Liquid-Phase Adsorption of Methylene Blue Using Cedar Sawdust and Crushed Brick. J. Hazard. Mater. 2006, 135, 264-273. [CrossRef] [PubMed]

44. Kumar, M.; Tamilarasan, R.; Sivakumar, V. Adsorption of Victoria Blue by carbon/Ba/Alginate Beads: Kinetics, Thermodynamics and Isotherm Studies. Carbohydr. Polym. 2013, 98, 505-513. [CrossRef] [PubMed]

45. Inyinbor, A.A.; Adekola, F.A.; Olatunji, G.A. Kinetics, isotherms and thermodynamic modeling of liquid phase adsorption of Rhodamine B dye onto Raphia hookerie fruit epicarp. Water Resour. Ind. 2016, 15, 14-27. [CrossRef]

46. Parvin, S.; Biswas, B.K.; Rahman, A.; Rahman, H.; Anik, S.; Uddin, R. Study on Adsorption of Congo Red onto Chemically Modified Egg Shell Membrane. Chemosphere 2019, 236, 124326. [CrossRef]

47. Roy, T.K.; Mondal, N.K. Biosorption of Congo Red from Aqueous Solution onto Burned Root of Eichhornia Crassipes Biomass. Appl. Water Sci. 2017, 7, 1841-1854. [CrossRef] 
48. Ghaedi, M.; Tavallali, H.; Sharifi, M.; Kokhdan, S.N.; Asghari, A. Preparation of Low Cost Activated Carbon from Myrtus Communis and Pomegranate and Their Efficient Application for Removal of Congo Red from Aqueous Solution. Spectrochim. Acta Part A Mol. Biomol. Spectrosc. 2012, 86, 107-114. [CrossRef] [PubMed]

49. Dawood, S.; Sen, T.K. Removal of Anionic Dye Congo Red from Aqueous Solution by Raw Pine and Acid-Treated Pine Cone Powder As Adsorbent: Equilibrium, Thermodynamic, Kinetics, Mechanism and Process Design. Water Res. 2012, 46, 1933-1946. [CrossRef]

50. Litefti, K.; Freire, M.S.; Stitou, M.; González-Álvarez, J. Adsorption of an Anionic Dye (Congo Red) from Aqueous Solutions by Pine Bark. Sci. Rep. 2019, 9, 1-11. [CrossRef]

51. Lian, L.; Guo, L.; Guo, C. Adsorption of Congo Red from Aqueous Solutions onto Ca-Bentonite. J. Hazard. Mater. 2009, 161, 126-131. [CrossRef]

52. Mane, V.; Babu, P.V. Kinetic and Equilibrium Studies on the Removal of Congo Red from Aqueous Solution Using Eucalyptus Wood (Eucalyptus Globulus) Saw Dust. J. Taiwan Inst. Chem. Eng. 2013, 44, 81-88. [CrossRef]

53. Naushad, M.; Ahamad, T.; Al-Maswari, B.; Alqadami, A.A.; Alshehri, S.M. Nickel Ferrite Bearing Nitrogen-Doped Mesoporous Carbon As Efficient Adsorbent for the Removal of Highly Toxic Metal Ion from Aqueous Medium. Chem. Eng. J. 2017, 330, 1351-1360. [CrossRef]

54. Yagub, M.T.; Sen, T.K.; Afroze, S.; Ang, H. Dye and Its Removal from Aqueous Solution by Adsorption: A Review. Adv. Colloid Interface Sci. 2014, 209, 172-184. [CrossRef] [PubMed]

55. Wong, S.; Tumari, H.H.; Ngadi, N.; Mohamed, N.B.; Hassan, O.; Mat, R.; Amin, N.A.S. Adsorption of Anionic Dyes on Spent Tea Leaves Modified With Polyethyleneimine (PEI-STL). J. Clean. Prod. 2019, 206, 394-406. [CrossRef]

56. Shang, Y.; Zhang, J.; Wang, X.; Zhang, R.; Xiao, W.; Zhang, S.; Han, R. Use of Polyethyleneimine-Modified Wheat Straw for Adsorption of Congo Red from Solution in Batch Mode. Desalination Water Treat. 2016, 57, 8872-8883. [CrossRef]

57. Wong, S.; Ghafar, N.A.; Ngadi, N.; Razmi, F.A.; Inuwa, I.M.; Mat, R.; Amin, N.A.S. Effective Removal of Anionic Textile Dyes Using Adsorbent Synthesized from Coffee Waste. Sci. Rep. 2020, 10, 1-13. [CrossRef] 